\title{
CONTRACTUAL OR DELICTUAL? ON THE CHARACTER OF PRE-CONTRACTUAL LIABILITY IN SELECTED EUROPEAN LEGAL SYSTEMS
}

\begin{abstract}
In this essay, the author aims to briefly analyze the character and application of the institutions which are functionally compared to culpa in contrahendo in four distinctly different legal systems, namely in English, French, German and Polish law by positioning them on the traditional contractual/ delictual liability axis. The author thereby hopes to gain a better insight into the essence of precontractual liability and aims to conclude by critically assessing the strengths and weaknesses of each system. The essay is structured into seven main parts: it begins with a short presentation of the institution's pedigree and a brief description of model regulations, namely PECL and DCFR. The opening part is followed by an analysis of four national interpretations of culpa in contrahendo. The article ends with the author's concluding remarks as to the character of pre-contractual liability.
\end{abstract}

\section{Keywords}

pre-contractual liability - delictual liability - contractual liability - comparative contract law European legal traditions

\section{INTRODUCTORY REMARKS}

Since its "rediscovery" in the nineteenth century, culpa in contrahendo, a brainchild of the prominent German jurist, Rudolf Jhering, has been steadily influencing modern legal systems for nearly two centuries ${ }^{1}$. Rooted

\footnotetext{
* University of Warsaw, College of Inter-Faculty Individual Studies in Humanities, Faculty of Law and Administration and Department of Sinology, dmichonski93@yahoo.com.

1 Jhering, in his search for the origins of pre-contractual liability, concentrated his studies on three main cases analysed by the Roman jurists: acting without the power of attorney, mistake, and selling a non-existent item. These cases are not representative for the present-day understanding of pre-contractual liability. The German scholar came to the conclusion that
} 
in Roman Law, but far removed from its ancient origins, the concept has undergone a complex process of evolution which, in all probability, is far from its conclusion Many controversies arising from international contract practice ${ }^{2}$, equally numerous doctrinal disputes and codification projects, the Principles of European Contract Law (PECL), and the Draft Common Frame of Reference (DCFR) to name a few, carried out by various international institutions are fueling the ongoing discussion about the meaning, scope and functions of culpa in contrahendo in modern-day civil law. In some countries (Austria, Germany, and Portugal), it is viewed as strictly contractual in its nature; in others it is associated almost exclusively with delictual liability (France and French-influenced legal systems), while occasionally it is claimed to be sui generis ${ }^{3}$. Often, it is utilised as

in all of the aforementioned instances, the party at fault has not exhibited sufficient diligence in contracting by inciting a false expectation in the other party. S. Kubsik, Przedkontraktowa odpowiedzialność odszkodowawcza z tytulu nieuczciwych negocjacji [Pre-contractual Liability Arising from Unloyal Negotiations], Warszawa 2016, p. 207. It is quite clear that from the beginning culpa in contrahendo was a rather patchy and flexible term encompassing numerous individual cases. What is more, in the years following Jhering's death, German jurisprudence considerably broadened the scope of its application. The only instance in which it is now applied that is similar to Jhering's ideas is the nullity of a juridical act due to wrong form. A. Bauknecht, Culpa in contrahendo wobec unifikacji prawa prywatnego w Europie [Culpa in contrahendo in the Context of the Unification of European Private Law], Berlin 2014, p. 11. As a result, the term has to be used with special care.

2 Most notably as to the prerequisites of liability (especially fault), the scope of damages and possible confluence of claims. M.A. Zachariasiewicz, Zasada dobrej wiary jako kryterium oceny zachowania stron w toku negocjacji w ujęciu prawnoporównawczym ("culpa in contrahendo") [The Principle of Good Faith as a Criterion of Evaluation of the Parties' Conduct during Negotiations in a Comparative Perspective ("culpa in contrahendo")], [in:] L. Ogiegło, W. Popiołek, M. Szpunar (eds), Rozprawy prawnicze: księga pamiatkowa profesora Maksymiliana Pazdana [Legal Discourse: Professor Maksymilian Pazdan's Commemorative Book], Kraków 2005, p. 1505.

3 Wendehorst mentions four different types of cases. Firstly, she observes that if the losses occur during contact between the parties which is established with the aim of concluding a contract, but which does not cause the contract's eventual non-conclusion, then in the majority of legal systems delictual liability is imposed. If contractual liability is applied in such instances, it is only due to the delictual liability regime's deficiencies in a given legal system, as for example is the case in German law. Secondly, if informational obligations are not observed, usually contractual liability is imposed. Thirdly, if the contract proves to be void and null or otherwise defective, contractual liability is most common. Fourthly, if the parties do not conclude a contract (e.g. negotiations are broken off) and losses occur, the liability regime choices vary according to political and historical criteria. Ch. Wendehorst, Culpa in contrahendo $z$ perspektywy prawnoporównawczej oraz w przyszłym europejskim prawie prywatnym [Culpa in contrahendo from a Comparative Perspective and in Future European Private Law], Kwartalnik Prawa Prywatnego [The Private Law Quarterly] 2012, no. 4, pp. 896-897. On the growing importance of the pre-contractual stage and EU law influence see A. Olejniczak, Problematyka culpa in contrahendo na tle europejskiego prawa umów [The Issue of Culpa in contrahendo in the Context of European Contract Law], [in:] M. Pazdan, W. Popiołek, E. Rott-Pietrzyk, M. Szpunar (eds), Europeizacja prawa prywatnego, t. II [Private Law Europeization, vol. II], Warszawa 2008, p. 90. 
a subsidiary measure for covering the deficiencies of other legal provisions which guarantee an insufficient level of protection for the parties' interests at the increasingly important pre-contractual stage, especially in the context of high European Union (EU) standards ${ }^{4}$. As was the case in the times of Jhering, so too at present, culpa in contrahendo may be seen as a means of adapting the law to the realities of modern-day business relations ${ }^{5}$.

In this essay, the author aims to briefly analyse the character and application of the institutions which are functionally compared to culpa in contrahendo in four distinctly different legal systems, namely in English, French, German and Polish law, by positioning them on the traditional contractual/delictual liability axis. The author thereby hopes to gain a better insight into the essence of pre-contractual liability and aims to conclude by critically assessing the strengths and weaknesses of each system. The essay is structured into seven main parts: it begins with a short presentation of the institution's pedigree and a brief description of model regulations, namely PECL and DCFR. The opening part is followed by an analysis of four national interpretations of culpa in contrahendo. The article ends with the author's concluding remarks.

\section{HISTORICAL BACKGROUND OF CULPA IN CONTRAHENDO}

In its original sense, culpa in contrahendo ${ }^{6}$ or "fault in contracting" applies to the culpable conduct of either of the contractors before the conclusion of the contract, most typically during negotiations, but not only in that instance, regardless of the actual conclusion of the contract ${ }^{7}$. Having

\footnotetext{
Wendehorst, supra note 3, p. 888.

5 P. Machnikowski, Odpowiedzialność przedkontraktowa - jej podstawy, przestanki i funkcje [Pre-contractual Liability - Its Basis, Prerequisites and Functions], [in:] M. Pazdan, W. Popiołek, E. Rott--Pietrzyk, M. Szpunar (eds), Europeizacja prawa prywatnego, t. I [Private Law Europeization, vol. I], Warszawa 2008, p. 706. Machnikowski believes that culpa in contrahendo is of paramount importance to modern-day economic relations as it helps protect trust, which is at the core of every economic transaction, and minimise risks stemming from the inevitable deficit of knowledge regarding the potential business partner. Therefore, culpa in contrahendo effectively constitutes an incentive to conclude contracts. A similar argument regarding the risks of a free market economy is also presented in P. Sobolewski, Odpowiedzialność przedkontraktowa [Pre-contractual Liability], [in:] Pazdan, Popiołek, Rott-Pietrzyk, Szpunar (eds), supra note 3, p. 393. On trust in negotiations see W. Kocot, Odpowiedzialność przedkontraktowa [Pre-contractual Liability], Warszawa 2013, p. 13.

6 The concept was first introduced in Jhering's 1861 essay entitled Culpa in contrahendo oder Schadenersatz bei nichtigen oder nicht zur Perfection gelangtei Vertragen.

7 Kubsik, however, argues that originally culpa in contrahendo pertained only to cases in which the contract had been concluded, but was later found to be void and null. Legal protection in cases of non-conclusion was granted later under the influence of the jurisprudence. Strangely, at present some authors claim the latter to be the "purest" form of culpa in contrahendo. Kubsik,
} 
spotted a loophole in German law, which in certain cases left the injured party with no legal means to recover damages, Jhering strove to bridge it by postulating that as soon as the two parties "enter into negotiations for a contract, [...] a relationship of trust and confidence comes into existence, irrespective of whether they succeed or fail" 8 and should at all times proceed in good faith. In such cases, although no formal bond exists between the two contractors, the party which abuses this distinctive mutual trust should shoulder the consequences of its conduct and bear the liability for the resulting damages, within the limits of the other side's "negative interest" or the damages which the side in good faith sustained relying on the completion of contract ${ }^{9}$. In this way, the injured party is granted a remedy even though no contract is yet in place. In order for it to encompass instances not only of dolus (intent) but also of culpa (negligence), the German jurist was forced to ground his concept in the contractual liability regime, as during his lifetime delictual liability was limited to cases of $d o l u s^{10}$. Jhering's historical take on the institution is considerably narrower than the presentday understanding of culpa in contrahendo, as contemporarily the tendencies to objectify the understanding aiming at separating pre-contractual liability from fault are steadily gaining acclaim ${ }^{11}$.

Presently, pre-contractual liability may arise as a result of various illegitimate practices of which only a few should be mentioned: deliberate non-disclosure of information relevant to the other side, entering into negotiations without the intent of concluding the contract (but in order to gain confidential information, to prevent the other party from concluding a contract with a third party, or to put pressure on another contractor), breach of confidentiality or a negotiation agreement drafted before the beginning of the entire negotiating process, breaking off negotiations with no reason or conducting parallel negotiations. Nevertheless, at the broader conceptual level, the idea seems to maintain its validity as a referential tool for lawyers all over the globe. It is highly unlikely that a universally

\footnotetext{
supra note 1 , pp. 10-11.

8 E. Fine, F. Kessler, Culpa in contrahendo, Bargaining in Good Faith, and Freedom of Contract. A Comparative Study, Harvard Law Review 1964, vol. 77, no. 3, p. 404.

9 There were some instances, however, in which Jhering opted for full compensation. Furthermore, Kubsik argues that Jhering's default choice of negative interest points to a delictual tint of culpa in contrahendo in its most original form, which would support the thesis that its creator aimed for pre-contractual liability to be a sui generis crossover between contractual and delictual liability. Kubsik, supra note 1, pp. 209-210. Kocot, on the other hand, views the negative contractual interest criterion as an emanation of contractual liability and claims that it is "alien to the delictual liability regime". Kocot, supra note 5, p. 153.

10 Kubsik, supra note 1, p. 210.

11 Ibidem, p. 10.
} 
applicable definition of the term will be put forth, as its semantic breadth effectively precludes any such effort. When referring to a specific legal system, however, Bauknecht, following in the footsteps of Andrzejewski, suggests that it would be more suitable from a terminological standpoint to use the modern term "pre-contractual liability"12.

After Jhering's research was published in 1861, the German doctrine anchored culpa in contrahendo in the principle of good faith and started expanding the concept, introducing new means of protection, e.g. the duty of disclosing matters which may be relevant to the other party, of which that party is not aware, and liability for disclosing false information (i.e. the principle of fair dealing). This expansion marked a retreat from the classical theory of contracts and the supremacy of the doctrine of will in favour of a shift towards a social theory of contract. The character of liability for culpa in contrahendo is debatable. However, owing both to the deficiencies of German tort law which lacks a unifying principle of liability and to the presupposition of fault characteristic of Jhering's concept ${ }^{13}$, the liability resulting from culpa in contrahendo has traditionally been classified as contractual liability ${ }^{14}$. After this short introduction to the topic, the second part of the essay provides an analysis of the institution in four distinct European legal traditions.

\section{MODEL REGULATIONS}

Owing to limitations of length, only two model codification efforts (PECL and DCFR) will be briefly analysed in this paper. The Principles of European Contract Law are the result of over 20 years of legal work conducted by the Commission on European Contract Law headed by Professor Ole Lando. Liability for negotiations is regulated by provisions included in Chapter 2 Section 3. Article 2:301 (1) $)^{15}$ establishes the freedom

\footnotetext{
12 Bauknecht, supra note 1, p. 23. Kubsik seems to echo this view, citing Sobolewski and Krajewski. Kubsik, supra note 1, p. 11, note 28.

13 Negligence, at the very least, which is in keeping with the main liability principle governing contractual liability in German law.

14 Fine, Kessler, supra note 8, p. 406.

15 Article 2:301 (ex art. 5.301) - Negotiations Contrary to Good Faith. (1) A party is free to negotiate and is not liable for failure to reach an agreement. (2) However, a party who has negotiated or broken off negotiations contrary to good faith and fair dealing is liable for the losses caused to the other party. (3) It is contrary to good faith and fair dealing, in particular, for a party to enter into or continue negotiations with no real intention of reaching an agreement with the other party. All PECL provisions have been taken from: Principles of European Contract Law - PECL, available at: http:/ / www.trans-lex.org/ 400200 [last accessed: 26.03.2016].
} 
to negotiate and excludes liability in cases of failure to reach an agreement. Article 2:301 (2) states that freedom of negotiations stretches as far as the principles of good faith and fair dealing. Actions (entering into, conducting, or breaking off negotiations) contrary to those two principles create liability of the actor for the losses caused thereby. Article 2:301 (3) provides an example of unfair negotiation practices (entering into or continuing negotiations with no real intention of reaching an agreement). According to Article 1:201 (2), the parties may not exclude the duties of acting in accordance with good faith and fair dealing. Article 2:302 ${ }^{16}$ states that the parties are obliged to maintain confidentiality of information ${ }^{17}$ received during the negotiations, regardless of the eventual conclusion of the contract, and establishes the dual remedies of compensation for loss and restitution of the benefits received by the party in breach ${ }^{18}$.

The Draft Common Frame of Reference (DCFR) is a product of codification efforts undertaken under the auspices of the European Commission with the aim of improving the quality and coherence of European civil law. It forms a set of "best solutions" taken from the member states' legal systems and therefore is a valuable reference tool both for legal scholars and for national legislators. The provisions regulating pre-contractual liability included in the DCFR form a common core of the European civil law tradition ${ }^{19}$.

Similarly to PECL, Article 3:301 (1) of the DCFR establishes a right to negotiate freely and excludes any liability for failure to reach an agreement ${ }^{20}$. Therefore, the parties may choose when to enter into

\footnotetext{
16 Article 2:302 (ex art. 5.302) - Breach of Confidentiality. If confidential information is given by one party in the course of negotiations, the other party is under a duty not to disclose that information or use it for its own purposes whether or not a contract is subsequently concluded. The remedy for breach of this duty may include compensation for loss suffered and restitution of the benefit received by the other party.

17 A major flaw of the provision is the fact that it does not specify which information is confidential. This is of paramount importance as the duties created by the regulation pertain only to confidential information.

18 It appears that a combination of the two is explicitly allowed by the provision.

19 Kubsik, supra note 1, p. 303.

20 II.-3:301: Negotiations contrary to good faith and fair dealing. (1) A person is free to negotiate and is not liable for failure to reach an agreement. (2) A person who is engaged in negotiations has a duty to negotiate in accordance with good faith and fair dealing and not to break off negotiations contrary to good faith and fair dealing. This duty may not be excluded or limited by contract. (3) A person who is in breach of the duty is liable for any loss caused to the other party by the breach. (4) It is contrary to good faith and fair dealing, in particular, for a person to enter into or continue negotiations with no real intention of reaching an agreement with the other party. All DCFR provisions have been taken from: Ch. v. Bar, E. Clive, H. Schulte Nölke (eds), Principles, Definitions and Model Rules of European Private Law: Draft Common Frame of Reference (DCFR) Outline Edition, Münich 2009, p. 193.
} 
negotiations, how and with which partner to negotiate, and when to break off the negotiations without suffering negative consequences. However, this freedom is not absolute, as the provision explicitly creates a duty of conducting negotiations in accordance with good faith and fair dealing (the positive aspect), while at the same time forbidding the parties to break off the negotiations in violation of good faith and fair dealing (the negative aspect). This method of regulation stands in contrast to the one used in Article 2:301 (2) of PECL, which considers exclusively the results of a breach of good faith and fair dealing. Similarly to PECL, however, entering into, continuing, or breaking off negotiations contrary to good faith and fair dealing create liability. Another innovation introduced by the DCFR is the fact that the parties may not exclude or limit liability arising from this provision. According to Article 3:501 of the DCFR, the liability is limited to the other party's negative interest and encompasses both material and immaterial loss, including loss of opportunities ${ }^{21}$.

Article 3:302 of the DCFR does not establish a duty to treat every piece of information obtained during negotiations as confidential ${ }^{22}$.Therefore, the negotiating parties may dispose of the said information according to their wishes, namely share them with third parties or use them when conducting other business operations. If a stipulation of confidentiality is made, however, the other party is obliged not to disclose or share the information obtained during the negotiations even after the negotiations have been broken off. The party in breach is liable for the resulting damages. Alternatively, the other party may choose to demand that the party in breach pay over the benefits which it has attained as a result of the breach.

\footnotetext{
${ }_{21}$ Kubsik, supra note 1, p. 303. Wendehorst argues that the negative contractual interest criterion indicates its contractual character. Wendehorst, supra note 3, p. 896. Kocot, on the other hand, is of the opinion that the model regulations constitute a departure from the traditional contractual/delictual regime duality and possess features of both of these regimes. Kocot, supra note 5, pp. 68-69.

22 II.-3:302: Breach of confidentiality. (1) If confidential information is given by one party in the course of negotiations, the other party is under a duty not to disclose that information or use it for that party's own purposes whether or not a contract is subsequently concluded. (2) In this Article, "confidential information" means information which, either from its nature or the circumstances in which it was obtained, the party receiving the information knows or could reasonably be expected to know is confidential to the other party. (3) A party who reasonably anticipates a breach of the duty may obtain a court order prohibiting it. (4) A party who is in breach of the duty is liable for any loss caused to the other party by the breach and may be ordered to pay over to the other party any benefit obtained by the breach. von Bar, Clive, Nölke (eds), supra note 20, p. 194.
} 


\section{ENGLISH LAW APPROACH}

In English law, no pre-contractual liability can be spoken of unless a contract is completed ${ }^{23}$. This legal difference seems to stem from a distinct, more liberal view of persons as economic agents possessing a considerable degree of independence and fully capable of consciously taking risks and bearing the consequences thereof. Individuals act in order to satisfy their personal economic needs and are best suited to devise plans leading to the achievement of their respective goals ${ }^{24}$. Rather than forming a tightlywoven net of socio-economic connections, they may be better understood as independent individuals with few obligations towards each other. Assuch, they should not beforced to bear the responsibility for the negligence of others. Consequently, two parties possess the freedom to both enter into and terminate negotiations without any consequences. This stance is sometimes described as an "all-or-nothing" approach - either the parties are conducting negotiations and have no obligations towards each other, in which case the court is not supposed to interfere in their affairs, or they are bound by a contract and may protect their interests in court. In comparison to continental law systems, state protection is thus considerably limited. Nogeneralduties ofnegotiatingingood faith, disclosingrelevantinformation or maintaining confidentiality exist in English law ${ }^{25}$. It may be argued, therefore, that the English rejection of the abstract notion of good faith is a political and philosophical manifesto ${ }^{26}$.

Nonetheless, English law recognises and defers to a notion of "fairness", rather than "social justice", which may be used to rectify contractual relations in certain cases ${ }^{27}$. Therefore, it can be seen that in a broader, conceptual sense, good faith is indeed present in English law. The difficulties start mounting only when we attempt to transform it into a general principle and impose it on the English courts, which are traditionally reluctant to accept any overarching principles. The main argument in favour of rejecting a general good faith principle raised by English jurisprudence is its abstract and vague character which, in turn, may prove good faith obligations to be unenforceable when applied

\footnotetext{
23 S. Banakas, Liability for Contractual Negotiations in English Law: Looking for the Litmus Test, Revista para el Analisis del Derecho, Barcelona 2009, p. 4.

24 As an example to illustrate this statement one could point to the caveat emptor (let the buyer beware) rule which is one of the principles of English contract law.

25 With the notable exception of consumer law.

26 Wendehorst, supra note 3, p. 895.

27 M. Piers, Good Faith in English Law - Could a Rule Become a Principle?, Tulane European \& Civil Law Forum 2011, vol. 26, p. 131.
} 
to specific cases $^{28}$. This view is an emanation of an ever-present and traditionally justified tendency in English law towards devising rules which are concrete, objective, and enforceable in individual cases rather than making use of general, abstract principles. However, due to the continuing harmonisation efforts undertaken by the EU, English law is being steadily infused with continental good faith rules, particularly in the field of customer-professional relations, and the English courts may not be awarded the luxury of rejecting continental concepts for much longer

It could be argued that the watershed case which established the English blueprint approach towards good faith is Walford $v$. Miles ${ }^{29}$. Decided by the House of Lords, it confirmed that a general good faith principle does not exist in English law. More specifically, the two parties - the seller (Miles) and the potential buyer (Walford) wished to enter into a lock-out agreement ${ }^{30}$. Miles promised Walford that he would neither consider nor accept any offers if Walford provided him with a letter of comfort from his bank, which requirement Walford promptly met. Miles, however, went back on his word and concluded a contract with a third party. In its holding, the House of Lords pointed out that a negotiation agreement of this type should clearly state the time frame of the seller's obligation, or otherwise it is unenforceable and creates uncertainty, as the seller does not know when the agreement is no longer binding. Furthermore, the House of Lords was of the opinion that the aims of the two parties of the contract are in permanent conflict and either of the sides has the right to withdraw from the negotiations as soon as it deems that withdrawal is necessary to protect its interests. Therefore, there is no "tacit agreement" between the parties to negotiate in good faith ${ }^{31}$.

In Petromec v. Petroleo ${ }^{32}$, however, the House of Lords, having distinguished the case from Walford $v$. Miles, deviated from the precedent stated thereinand allowed the two parties toenter a binding agreement which expressly stated the rather general obligation of conducting negotiations in good faith ${ }^{33}$. However, the legal status of such an agreement hinges upon

\footnotetext{
Ibidem, p. 127.

Walford v. Miles, [1992] 2 AC 128.

A contract forbidding one or both parties to seek or accept offers from third parties. Provided that it clearly states the time period of the obligation, it is legally binding. A lock-in agreement, on the other hand, is an agreement in which the parties agree to negotiate in good faith. Along the lines of the rationale presented in Walford, it is believed to be unenforceable according to English law. Kubsik, supra note 1, p. 280.

31 Piers, supra note 27, p. 135.

32 Petromec Inc. Petro-Deep Societa Armamento Navi Appoggio SpA v. Petroleo Brasileiro SA, [2006] EWHC 1443 (Comm).

33 Piers, supra note 27, pp. 137-138.
} 
a clear formulation of the parties' obligations (a detailed explanation of what the parties mean by good and bad faith) and the judges' ability to determine the nature, scope and consequences of the breach. The tendency to acknowledge adequately concretised good faith veiled in the parties' will seems to be steadily gaining judicial acclaim ${ }^{34}$. Another exception to the rule is the so-called uberrimae fidei or "utmost good faith", typical for contractual relations in which one party is at a clear informational advantage in comparison to the other party. After the conclusion of a contract, this advantageous position creates a duty of disclosure of facts relevant to that contract. However, the application of utmost good faith is limited only to certain types of contracts, of which the insurance contract may be the most representative example. At the pre-contractual stage, uberrimae fidei entails the duty of disclosing relevant facts even if no inquiries are made. If this duty is not observed, the other party may avoid the contract ${ }^{35}$. Fiduciary relationships, long-term business relations and partnership agreements are three other instances in which a special relationship of trust between the two parties is mandatory ${ }^{36}$.

Contrary to employing abstract, general concepts in the spirit of good faith, English law strives to achieve contractual fairness by employing casuistic means, which may be functionally compared to the principle of culpa in contrahendo. The three major legal principles of this kind employed when a contract has been concluded despite causes for imposing precontractual liability are: duress, undue influence, and misrepresentation. Firstly, duress is a form of illegal pressure which may take the form of duress to a person, duress to goods, or economic duress. When consenting to a contract under duress, the party's freedom of decision is severely limited and so the legitimacy of the contract is highly doubtful. Secondly, the doctrine of undue influence aims to complement the institution of duress. It pertains to subtler forms of coercion and is relevant in two groups of situations, namely: a) when the offer is accepted after pressure has been exerted or, b) when illegal influence is presumed after certain facts have been proven. Thirdly, misrepresentation may be defined as making unclear or false statements of fact or law which are instrumental to the counterparty's decision of entering into a contract. Misrepresentation may be intentional (fraudulent), negligent, or "innocent", which is neither intentional nor negligent ${ }^{37}$. The available remedies are rescission of the

\footnotetext{
Kubsik, supra note 1, p. 283.

Piers, supra note 27, pp. 158-159.

Kubsik, supra note 1, p. 95.

37 Culpa in contrahendo may occasionally be classified as an economic tort in the case of
} 
contract or applying for remedy of damages in the two former cases of misrepresentation $^{38}$. In some instances, the court may also give relief to one party by means of the equitable doctrine of estoppel ${ }^{39}$ or restitution due to unjust enrichment. Moreover, a fundamental mistake which induced a party to enter into a contract also constitutes a basis for rescission. Entering into negotiations without the intent to conclude a contract may be qualified as deceit. In cases of termination of the negotiations at an advanced stage, the court may make use of the implied contract doctrine, effectively enforcing a contract before its formal conclusion ${ }^{40}$. On the whole, it could be argued that a piecemeal approach characteristic of English law provides inadequate means of remedy for damages sustained at the pre-contractual phase. The arguments used by the English courts to reject the abstract notion of good faith seem outdated and ill-suited to the harsh realities of a modern-day market economy. As a result, the contracting parties are left with few reliable legal tools to guard themselves against unfair practices which do not correspond with the traditional common law institutions.

\section{FRENCH LAW APPROACH}

The French Code Civil does not contain provisions specifically relating to liability stemming from the negotiation period ${ }^{41}$. However, Articles 1134, 1135, together with 1382 and $1383^{42}$ form the legal basis for pre-contractual liability in the French legal system. The Code explicitly voices out the principle of contract as law made by two parties. Such a bold statement poses

misrepresentation. However, it has to be noted that English courts are rather reluctant to grant awards for pre-contractual liability on the basis of tortious liability.

38 Piers, supra note 27, pp. 154-156.

39 “(...) Proprietary estoppel exists to adjust the prevailing balance of property between claimant and defendant when the claimant has formed the relevant kind of expectation, and has acted detrimentally in reliance on it, and these occurrences are ascribable to the defendant (via his encouragement of or acquiescence in them), so that it would be unconscionable for him to insist on the status quo (...)"; Banakas, supra note 23.

40 Kubsik, supra note 1, pp. 278-279.

41 F. Caterini, Pre-contractual Obligations in France and the United States, Athens Georgia 2004, unpublished, p. 4.

42 Article 1134: Agreements lawfully entered into have the force of law for those who have made them. They may be revoked only by their mutual consent, or for causes allowed by law. They must be performed in good faith. Article 1135: Agreements bind not only as to what is therein expressed, but also as to all the consequences that equity, usage, or law impose upon the obligation according to its nature. Article 1382: Every act whatever of man that causes damage to another, obliges him by whose fault it occurred to repair it. Article 1383: We are responsible not only for the damage occasioned by our own act, but also by our own negligence or imprudence. All provisions have been taken from: Code civil, available at: http://www. legifrance.gouv.fr/Traductions/en-English/Legifrance-translations [last accessed: 1.01.2016]. 
difficulties in introducing a concept limiting the freedom of the contracting parties. Thus, the French doctrine had to devise another way of introducing culpa in contrahendo into the legal system ${ }^{43}$. This aim was achieved by way of creative interpretation of the already extant legal provisions. In French law, in contrast to German law, culpa in contrahendo is subject to delictual liability. Similarly, the parties have certain obligations towards each other even before formally entering into a contract. However, these obligations are not imposed on the parties by any contract, be it statutory or voluntary. As a result, conduct contradictory to them will be classified as a delict, not a breach of contract ${ }^{44}$. Article 1382 mentions three main criteria necessary for tortuous liability: a) an act of a man, b) emerging damage in causal link with that act and c) fault. Article 1383 elaborates on the preceding provision and expands the fault criterion by introducing negligence and imprudence. Kubsik lists four main cases in which pre-contractual liability may be imposed in the context of negotiations according to French law: a) entering into or conducting negotiations without the intent to conclude the negotiated contract, b) exposure or use of confidential information, c) refusal to cooperate during the course of the negotiations and d) premature termination of negotiations, provided that the other party could reasonably expect the contract to be concluded ${ }^{45}$.

Another important difference is that French law allows for full compensation of the damages sustained during pre-contractual negotiations as it does not make common use of the term "pure economic loss" native to English law ${ }^{46}$. Damages may include the costs of the negotiations, lost profits, losses caused by disclosure of confidential information, and, lastly, moral losses sustained as a result of violation of personal rights such as privacy and right of personal portraya ${ }^{47}$. Recently, a doctrinal and judicial

\footnotetext{
43 Two alternative solutions proposed by members of the French doctrine include: abuse of the right to negotiate and unjust enrichment. It has been decided, however, that unjust enrichment may be applied only in cases in which neither delictual nor contractual liability is imposable. Kubsik, supra note 1, p. 259. Some authors claim that pre-contractual liability in France stems from the abuse of rights concept. M. Rzewuska, M. Rzewuski, Odpowiedzialność deliktowa a odpowiedzialność kontraktowa w aspekcie culpa in contrahendo [Delictual and Contractual Liability in the Aspect of Culpa in contrahendo], [in:] M. Nesterowicz (ed.), Czyny niedozwolone w prawie polskim i prawie porównawczym. Materiały IV Ogólnopolskiego Zjazdu Cywilistów, Torun 24-25.06.2011 [Torts in Polish and Comparative Law. Postconference Materials from the Polish Civil Law Jurists Congress, Toruń 24-25 June 2011], Warszawa 2012, p. 404.

44 P. Giliker, A Role for Tort in Pre-contractual Negotiations? An Examination of English, French, and Canadian Law, The International and Comparative Law Quarterly 2003, vol. 52, no. 4, p. 970.

$45 \quad$ Kubsik, supra note 1, p. 257.

46 Giliker, supra note 44, p. 980.

47 Kubsik, supra note 1, p. 257.
} 
tendency to limit the extent of the liability to the injured party's negative interest (possibly including profits lost by not entering into an alternative contract with a third party) has surfaced ${ }^{48}$.

In France, as is the case in England, the duty of delimiting the scope of liability was put into the hands of the courts and the doctrine. Originally, a conservative stance dominated, advocating strict protection of the parties' freedom to negotiate and limiting pre-contractual liability to instances of dolus $^{49}$. The key case which changed the legal status quo was the 1972 holding of the Cour de cassation in Gerteis c/Vilbert-Lourmat ${ }^{50}$. The facts of the case were as follows: a distributor of pipe-manufacturing machines first withheld information during a contractor's visit to the US branch of the company to later terminate all negotiations and conclude a contract with the visiting contractor's competitor. In addition, the contract obliged the distributor not to sell any machines of similar type in the region where the two competing entrepreneurs were conducting business operations. Basing its decision on premises such as: a) the distributor's awareness of the expenses incurred by the contractor, $b$ ) the unnecessarily prolonged termination of the negotiations which c) induced the contractor to believe that a contract would be imminent and d) the sudden, unreasonable and unilateral character of the termination, the Cour held that the distributor committed a delict and was subject to liability ${ }^{51}$. In a more recent case from 1998, Sandoz ${ }^{52}$, the two parties have been conducting negotiations for nearly four years before one of them withdrew citing "internal difficulties". The Cour found that the withdrawing party exhibited a lack of loyalty and had to face delictual liability, due to the fact that it could not present a valid cause for its withdrawal. Nevertheless, the courts do allow withdrawal even in very advanced stages of negotiations, provided that the withdrawing party gives a substantial reason, e.g. financial difficulties or change of circumstances ${ }^{53}$. Although the courts agree that the parties are free to break off negotiations, some restricting factors have also been pointed out, namely: the length and intensity of negotiations pointing to the conclusion of contract, encouragement to take certain expenses or suddenness of termination. In such an instance, withdrawal is wrongful and procures losses which should be reimbursed. From the criteria mentioned

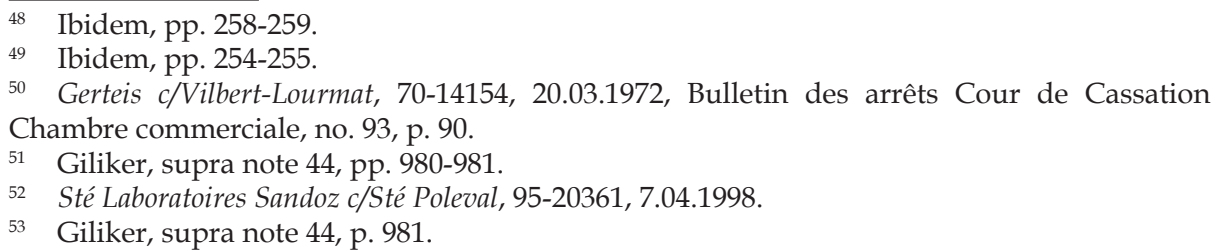


above, it may be deduced that at the preliminary stage of negotiations the imposition of pre-contractual liability is exceedingly rare and limited almost exclusively to instances of patent faul ${ }^{54}$. Other doctrinal theories list objective criteria such as "acting in bad faith", "lack of necessary diligence", " acts contrary to the principle of good faith" or "abused trust" 55 . Lack of intent may be another cause for liability as evidenced by the Ossona c/Al Esayi ${ }^{56}$ case, in which a party, being aware that he would need a bank loan to perform the contract, let the other party believe that he was solvent and withdrew from the negotiations only at the last moment because he had been denied a loan ${ }^{57}$.

Generally speaking, pre-contractual obligations between parties appear only after a certain period of time has elapsed and a bond of trust has been formed. The duties of the contracting parties may be grouped into four conceptual clusters: a) the duty to cooperate or to share information about the parties' intentions and wishes, b) the duty of counsel understood as maintaining dialogue, c) the duty of good faith or the duty to continue dealing until an agreement is reached or one of the parties withdraws due to a reasonable cause and d) the duty of loyalty or a situation in which both parties may enjoy freedom of contracting without deceitfulness ${ }^{58}$.

In sharp contrast to English law, a pre-contractual obligation to disclose, as well as not to omit any relevant information has been established by the courts ${ }^{59}$. Illegitimate use of confidential information acquired during the negotiations is classified as "disloyal competition" and amounts to fault. Parallel negotiations, on the other hand, are generally deemed acceptable, unless the parties agreed otherwise. There are two quite obvious exceptions to this general rule, that is: a) when a party is conducting negotiations at a significantly higher price with one contractor while simultaneously negotiating at lower prices with other contractors, and b) when a party induced the contractor to believe that it was only conducting negotiations with that particular contractor and that a contract was imminent, but was, in fact, dissimulating negotiations with a third party ${ }^{60}$. As it can therefore be seen, French courts, making full use of the quite broad provisions of Articles 1382 and 1383, adopt a more flexible approach towards culpa in

\footnotetext{
54 Kubsik, supra note 1, p. 256; Zachariasiewicz, supra note 2, p. 1507. The subjective element of fault is therefore more pronounced than the objective illegality of the act.

55 Kubsik, supra note 1, p. 256.

56 Ossona c/Al-Esayi, JCP 1998 II 10066, 6.01.1998.

57 Giliker, supra note 44, p. 982.

58 Rzewuska, Rzewuski, supra note 43, p. 404.

59 Caterini, supra note 41, p. 28.

60 Giliker, supra note 44, pp. 983-984.
} 
contrahendo than their English counterparts and are generally more willing to intervene and impose delictual liability on the party which was at fault in order to protect the weaker party. Another prominent feature of the French solution is the strong focus on delictual fault and the psychological attitude of the party in breach, which may be one of the causes of the French courts' paternalistic stance.

\section{GERMAN LAW APPROACH}

Before 2001, culpa in contrahendo was by and large an institution devised by jurisprudence in order to give remedies to contractors in certain situations in which previously no action could be taken according to the literal meaning of Bürgerliches Gesetzbuch (BGB) provisions ${ }^{61}$. A long, 30-year preclusion term and an advantageous burden of proof model caused it to become a "multifunctional instrument with a broad spectrum of applications" ${ }^{62}$. Since the 2001 reform of German contract law, pre-contractual obligations of the parties have been explicitly stated in Sections 241 (2), 242, 280 (1) and 311 (2) of the BGB $^{63}$. The principle of Treu und Glauben or "sincerity and faith" set up by Section 242 was used by the courts to impose liability in cases of culpa in contrahendo before $2002^{64}$.

\footnotetext{
61 The two main deficiencies of BGB's delictual liability regime are: lack of a general definition of a delict and Article 831 which allows for the principal to be absolved of liability for vicarious agents. Rzewuska, Rzewuski, supra note 43, p. 402.

${ }_{62}$ J. Andrzejewski, Czy nowa kodyfikacja prawa cywilnego jest potrzebna w czasie kryzysu prawa? [Is a New Code of Civil Law Necessary in Times of Legal Crisis?], Ruch Prawniczy, Ekonomiczny i Socjologiczny [Legal, Economic and Sociological Movement] 2014, no. 1, p. 84.

63 Section 241: (2) An obligation may also, depending on its contents, oblige each party to take account of the rights, legal interests and other interests of the other party. Section 242: An obligor has a duty to perform according to the requirements of good faith, taking customary practice into consideration. Section 280: (1) If the obligor breaches a duty arising from the obligation, the obligee may demand damages for the damage caused thereby. This does not apply if the obligor is not responsible for the breach of duty. Section 311: (1) In order to create an obligation by legal transaction and to alter the contents of an obligation, a contract between the parties is necessary, unless otherwise provided by statute. (2) An obligation with duties under section 241 (2) also comes into existence by: 1. the commencement of contract negotiations 2. the initiation of a contract where one party, with regard to a potential contractual relationship, gives the other party the possibility of affecting his rights, legal interests and other interests, or entrusts these to him, or 3. similar business contacts. (3) An obligation with duties under section 241 (2) may also come into existence in relation to persons who are not themselves intended to be parties to the contract. Such an obligation comes into existence in particular if the third party, by laying claim to being given a particularly high degree of trust, substantially influences the pre-contract negotiations or the entering into of the contract. All BGB provisions taken from: Bürgerliches Gesetzbuch, available at: http:/ / www.gesetze-iminternet.de/englisch_bgb/englisch_bgb. html\#p0434 [last accessed: 1.01.2016].

64 A number of theories as to the source of the obligations of the contracting parties have been
} 
In the context of culpa in contrahendo, the frequent references to the hallowed principle of German law possessed strong ethical undertones, as various jurists often cited values such as "justice", and "equality", and claimed to be acting in accordance with "overriding principles" ${ }^{65}$. With the addition of Section 311, this necessity disappeared. According to Section 311, when the parties enter into negotiations (in one of the three ways described in the provision), a quasi-contractual relation is formed ex lege $e^{66}$. On the basis of this pre-contractual agreement, both sides should proceed in good faith, taking into consideration the rights (e.g. life, health, reputation, property) and interests (both legal and other, e.g. factual interests) of the other party, in compliance with the contractual loyalty principle. What is more, in certain cases a third party (an agent, an intermediary or a messenger) may be liable for the damages ensuing from the breach of pre-contractual duties. The relative vagueness of the provision puts the initiative in the hands of the courts and gives them tools to shape culpa in contrahendo in response to the rapidly evolving economic reality ${ }^{67}$.

If: a) any of the aforementioned obligations are breached, b) the obligor is responsible for that breach ${ }^{68}, \mathrm{c}$ ) damages are sustained by the other side and d) there is a causal relation between the breach and the damages, the obligee may demand damages from the obligor. The breach must fulfill specific criteria, namely: a) it must have happened after the contracting parties have entered into the quasi-contractual ex lege relationship, b) one of the negotiating parties has to inspire in the other

put forth, among which the most prominent are: the "silent contract" theory (Vorvertrag), the "social contract" theory (sozialer Vertrag) and the "advance effect/pre-effect of the contract" (Vorwirkung des Vertrages). None of them, however, managed to adequately explain why an unconcluded contract created obligations for the parties. Kocot, supra note 5, p. 114.

65 Kubsik, supra note 1, p. 89. Unlike Jhering, who chose to boost his claims by basing his findings on Roman Law. It appears that in expressing revolutionary views, members of the doctrine and of the judiciary frequently feel the need to appeal to historical authority or ethical values.

${ }_{66}$ The majority of German jurists seem to share the view that culpa in contrahendo constitutes an example of contractual liability. However, some scholars, trying to point to a "third way" prefer to describe it as an instance of "unspecified" liability, "suspended" somewhere between delictual and contractual liability. Kubsik, supra note 1, p. 243; Rzewuska, Rzewuski, supra note 43 , p. 403 . Wendehorst brings up the view of R. Reischauer, who claims that it is a "modification of delictual liability". Wendehorst, supra note 3, p. 888.

67 Kubsik, supra note 1, pp. 244-245.

68 Traditionally, fault in establishing trust was required to impose liability on a contracting party. However, owing to doctrinal influences, the concept of fault in case of culpa in contrahendo has undergone a process of objectivisation and since 1989 has been linked with the unjustified termination of negotiations. Some scholars criticise this tendency by pointing out that fault is a necessary condition for imposing contractual liability and, by extension, should also apply to pre-contractual liability. If one were to suppose otherwise, culpa in contrahendo would effectively become contrahendo sine culpa. Kubsik, supra note 1, pp. 251-252. 
an above-average belief that the contract will be completed, c) one of the negotiating parties must have terminated the negotiations in abuse of the other party's trust (contrary to the contractor's belief that the contract will be concluded) without giving a valid reason for having done so, or as a result of the other party's disloyal behaviour ${ }^{69}$. Kubsik points to three main groups of situations in which culpa in contrahendo comes into play: a) personal injury sustained before the conclusion of a contract, b) instances when a concluded contract turns out to be undesirable or onerous due to the other party's disloyal behaviour at the pre-contractual stage and c) cases in which no contract has been concluded as a result of formal defects ${ }^{70}$. A rather counter-intuitive example of pre-contractual liability is discussed in an article by Kwaśnicki and Lewandowski ${ }^{71}$, who cite a case in which the court held that personal injury sustained by a child, whose mother had not entered into a sales contract, as a result of the shopkeeper's faulty placement of linoleum rolls was a cause of culpa in contrahendo ${ }^{72}$.

The parties have the duty of disclosing information relevant to the other party, also without the other party's inquiry into that matter. The disclosed information should be truthful and complete at all times. If the obligor intentionally or negligently discloses false information, he will be liable for the ensuing damages. In some cases, non-disclosure is permitted, as both parties should exert their efforts towards acquiring information. Putting all the responsibility in this respect on the shoulders of one party could, therefore, be seen as unjust. However, professional customs and the obligee's good faith may create a duty for the obligor to disclose information ${ }^{73}$.

In general, termination of negotiations is accepted by jurists as an emanation of the freedom of contract principle. However, if, having instilled in the other party a belief that the conclusion of the contract is imminent, one of the parties terminates negotiations without giving a valid reason for its action, the other party may demand expenses which had been incurred prior to the termination in the belief that the successful conclusion of the talks was certain. Pre-contractual liability may also arise in cases of

\footnotetext{
Ibidem, pp. 248-249.

Ibidem, p. 247.

R. Kwaśnicki, R. Lewandowski, Culpa in contrahendo w prawie polskim oraz niemieckim [Culpa in contrahendo in Polish and German Law], Prawo Spółek [Corporate Law] 2002, no. 5, p. 37.

72 As Wendehorst observes, in the so called linoleum roll case the injuries sustained are wholly unrelated to the conclusion of the contract. Wendehorst, supra note 3, p. 887 . The counterintuitiveness of the case manifests itself in the fact that the contrahendo component is difficult to spot. The intent of concluding a contract is not manifested clearly and so it can be argued that the parties are not negotiating.

${ }^{73}$ Kwaśnicki, Lewandowski, supra note 71, p. 38.
} 
legal nullity of a contract for which a party was responsible (which either occurred intentionally or as a result of negligence). The injured party may not only demand the expenses which were unnecessarily incurred in the belief that the contract would be concluded, but also the profit which would have been attainable had the party in fault behaved in accordance with the respective provisions ${ }^{74}$. It is worth noting that it is not necessary that the terminating party had no intention of concluding the contract from the very beginning of the negotiations in order for it to bear responsibility. On the contrary, if it loses that intent during the course of negotiations and does not inform the other party, it is still liable for damages ensuing from the moment of the loss ${ }^{75}$. Evidently, the German model of protection, based on contractual liability, is much more advanced than either the English or the French one. However, the German solution is not without its shortcomings as evidenced by the already mentioned linoleum roll case. The implied trust concept stemming from the Treu und Glauben principle may in some cases lead to judicial misuse of provisions governing culpa in contrahendo as it encourages the courts to hold the contracting parties to high ethical standards and forms an incentive for rulemaking activities. Those activities, while no doubt aimed at achieving contractual fairness, may in actuality harm the contracting parties.

\section{POLISH LAW APPROACH}

The general principles of Polish contract law do not contain provisions which pertain to pre-contractual negotiations. This area is instead regulated by the Articles $72 \S 2$ and $72^{1}$ of the Polish Civil Code added in $2003^{76}$. Article $72 \S 2^{77}$ has two main functions: firstly, it imposes the dual duties

\footnotetext{
$74 \quad$ Kwaśnicki, Lewandowski, supra note 71, pp. 38-39.

75 Kubsik, supra note 1, p. 252.

76 Art. $72 \S 1$. If the parties hold negotiations in order to execute a specific contract, the contract is executed when the parties reach an agreement on all the provisions which were the subject of the negotiations. § 2 . A party which enters into or conducts negotiations in breach of good custom, in particular without intending to execute a contract, is obliged to remedy any damage which the other party suffers by the fact that it was counting on the contract being executed. Art. $72^{1} \S 1$. If, during negotiations, a party makes information available with a stipulation of confidentiality, the other party cannot disclose or submit the same to other persons or use the same for its own purposes unless the parties agree otherwise. $§ 2$. In the case of non-performance or improper performance of the obligations referred to in $\S 1$, the entitled party may demand that the other party remedy any damage or hand over any benefits which it has obtained. Polish Civil Code provisions taken from: The Polish Civil Code, available at: https://supertrans2014.files.wordpress.com/2014/06/the-civil-code.pdf [last accessed: 1.01.2016].

77 To date, there have been relatively few cases arising from Article $72 \S 2$. As a result, the
} 
of loyalty and sincerity on all negotiating ${ }^{78}$ parties (the general clause of good custom ${ }^{79}$, albeit it does so indirectly by sanctioning acts which violate good custom), and secondly, it guarantees the remedy of damages in case the parties choose not to enter into a negotiation agreement ${ }^{80}$. Before the introduction of provisions regulating culpa in contrahendo into the Polish Civil Code, damages caused by the faulty behaviour (viewed as violating the rules of social coexistence) of a contractor were sought on the grounds of Article 415, which, utilising a mechanism similar to the French Code Civil, establishes a general principle of delictual liability. Before the legal reform of 2003, it was this behaviour, therefore, rather than an implicit pre-contractual agreement, which constituted the source of the obligation to remedy the damages ${ }^{81}$. With regard to the source of liability, the two most widely supported theories devised by the Polish doctrine are: a) the German - inspired "silent contract" theory, stipulating that, as soon as the parties start negotiating, they enter into an agreement obliging them not to cause damages to the other side ${ }^{82}$, and b) the delictual liability theory, stipulating that liability is construed according to the standards set out in Article $415^{83}$. A third theory, claiming that liability on the grounds of culpa

courts did not have many chances to resolve the numerous doubts surrounding it. It should also be observed that the decision of the legislator to introduce this provision was rather haphazard and poorly justified. Thus, the doctrine seems quite reluctant to change its stance and prefers to abide by the old and tried solutions.

78 The scope of the discussed provision's application is ex lege limited to negotiations. However, if the parties first conduct negotiations to eventually conclude a contract by way of offer and acceptance, Article $72 \S 2$ also applies. Only if the parties at no point make use of negotiations is the provision excluded. Rzewuska, Rzewuski, supra note 43, p. 408; Kocot, supra note 5, p. 158. Kocot points out that negotiations may be regarded as "the most uncertain and unpredictable sphere of contract law". Ibidem, p. 10.

79 Puzzlingly, the choice of this criterion has been approved by Olejniczak, who lauds its objectivity after having agreed with Janiszewska's proposal to employ the good faith clause instead. Olejniczak, supra note 3, pp. 96-97. Interestingly, Zachariasiewicz observes that "good faith and fair dealing" form a conceptual unity in which the first element is more subjective (describing the mindset of a contractor) while the second one - more objective (referencing the rules of honesty). Zachariasiewicz, supra note 2, p. 1516. A critique of the vagueness and casuistic character of the good custom clause is expressed in Rzewuska, Rzewuski, supra note 43, p. 420.

80 W. Czachórski, Zobowiązania. Zarys wykładu [Obligations. Outline of the Lecture], Warszawa 2009, p. 180.

81 The ongoing debate among the members of the Polish jurisprudence concerning the source of pre-contractual liability reaches back to the first half of the $20^{\text {th }}$ century and has been fueled by the legislator's reluctance to regulate this matter. Kubsik, supra note 1, pp. 221-222.

${ }_{82}$ The main objection to this theory is that it creates an obligation without clarifying the mode of its performance, as a general duty to negotiate loyally and with diligence is too vague. Olejniczak, supra note 3, p. 89.

83 Czachórski, supra note 80, p. 179; Rzewuska, Rzewuski, supra note 43, p. 406; Kocot, supra note 5, p. 152. Kocot argues that the delictual liability theory was formed in rejection of the German concepts and is insufficiently justified. Ibidem, p. 152. 
in contrahendo has a quasi-delictual character (a "broken delict" $[\text { sic }]^{84}$ ) is also present. Another theory, put forth by Sobolewski, states that Article $72 \S 2$ is a new type of liability which the author calls "pre-contractual liability" 85 . The delictual liability theory is shared by the judicial majority ${ }^{86}$.

Going along the lines of the traditional view presented by Czachórski, apart from the objective element (a breach of good custom which constitutes a delict ${ }^{87}$ ), fault must also be established ${ }^{88}$. The question of fault in the context of pre-contractual liability has been widely debated by the Polish jurists. Representing a traditional approach, Olejniczak claims that fault is the general principle ruling delictual liability. Therefore, in the case of pre-contractual liability on the basis of Article $72 \S 2$, which, according to him, does not bring any "revolutionary changes" and falls under the delictual liability regime, it is necessary to accept fault as the liability principle, even though fault is not explicitly voiced in the provision ${ }^{89}$. Machnikowski, on the other hand, disagrees with Olejniczak's thesis by stating that the legislator did not create a closed catalogue of liability principles. Instead, Machnikowski argues, those principles may in fact be viewed as a concretisation of a much more fundamental principle -

\footnotetext{
84 A term proposed by Pilich. Rzewuska, Rzewuski, supra note 43, p. 411. W. Kocot proposes a much more fortunate term, not unlike the German "third way" concept, calling it "sui generis liability" or "ex culpae in contrahendo liability". The author also highlights the placement of the provisions (in Book One "General Provisions" as opposed to Book Three "Obligations" Title VI "Tort") as proof of its sui generis character. Kocot, supra note 5, p. 66. Nonetheless, such a view entails many practical difficulties, especially if one operates under the assumption that the Polish Civil Code in its present shape is based exclusively on two main types of liability, namely contractual and delictual liability. If one were to assume that Article $72 \S 2$ created a new type of liability, it would be impossible to make use of preferential provisions regulating delictual liability, namely Articles $441^{1}$ and 442 of the Polish Civil Code. Kubsik, supra note 1, p. 308-310; Rzewuska, Rzewuski, supra note 43, pp. 410-411. It should be noted that there are scholars who, in stark contrast to Kocot's views, point out that Article $72 \S 2$ is redundant. According to them, only if necessary provisions were introduced into the Code, could a new "pre-contractual liability regime" come into being. Until then, provisions governing delictual liability should be applied to cases of culpa in contrahendo. Rzewuska, Rzewuski, supra note 43, p. 420.

85 Ibidem, p. 411.

86 Ibidem, pp. 411-412.

87 As Andrzejewski points out, good custom is not a standard inherent in a market economy based on competition. He also expresses his concern for entrepreneurs whose business activities may be subjected by the courts to excessive scrutiny. Andrzejewski, supra note 62, p. 88 .

${ }_{88}$ Kubsik disagrees and points out that the subjective attitude of the party in breach is not relevant to the question of liability. What matters is the objective breach of the duty to negotiate in accordance with good custom (the behaviour of the liable party). Kubsik, supra note 1, p. 309.

89 Projecting his personal stance towards the problem on the regulation, Olejniczak points out that "it would be advisable to underline the role of fault in the respective provisions". Olejniczak, supra note 3, p. 95.
} 
justice. The various liability principles represent a purely doctrinal device, by and large dependent on the present shape of the law, and therefore should not be used by legal scholars to mould new legal institutions into a shape that would fit the current state of their debates ${ }^{90}$. Moreover, Machnikowski remarks that, contrary to Olejniczak's conviction about the primacy of the fault principle, cases of strict liability (independent from fault) in the delictual liability regime, can be found in the Polish Civil Code $^{91}$. Machnikowski is, therefore, of the opinion that the discussed provision constitutes a self-standing base for liability ${ }^{92}$. Kubsik introduces further points in favour of that view by remarking that the legislator's intention in introducing the new regulations was to objectivise (eliminate the fault prerequisite) and broaden the scope of pre-contractual liability and not to limit $i t^{93}$. If one were to operate under a contrary assumption, Article $72 \S 2$ would be superfluous, as the protection based on the fault principle from Article 415 would have sufficed ${ }^{94}$. What is more, the author points to the fact that model regulations like PECL and UNIDROIT, which were an inspiration to the authors of Article $72 \S 2$, do not contain any mention of fault and sanction, only behaviour contrary to good faith and fair dealing in the case of the former and bad faith in case of the latter ${ }^{95}$.

To sum up the above, four elements in total have to be proved in order for the provision to be applied: a) entering into or conducting negotiations in a manner which contradicts good custom ${ }^{96}, b$ ) fault (depending on the author $)^{97}$, c) damages sustained by the other party, and d) a causal relation

\footnotetext{
$90 \quad$ Machnikowski, supra note 5, p. 714.

91 Article 417 of the Polish Civil Code. Kubsik, supra note 1, p. 312-313. Some scholars try to base liability from Article $72 \S 2$ on the so-called "illegality principle" formerly brought up in the context of Article 417. Kubsik discusses this on pp. 318-320. Kocot, on the other hand, proposes the so-called principle of risk. Kocot, supra note 5, p. 154.

${ }_{92}$ Machnikowski, supra note 5, p. 716. Kubsik affirms this view. Kubsik, supra note 1, p. 322; Kocot, supra note 5, p. 152. Kocot argues that pre-contractual liability combines contractual (a violation of inter partes obligations of loyalty and trust related to the conclusion of a contract, remedy of damages limited to negative contractual interest) and delictual elements (a breach of widely accepted rules of conduct constituting a delict). Ibidem, p. 152.

93 Similarly ibidem, p. 150.

94 Similarly Sobolewski, supra note 5, p. 400.

95 Kubsik, supra note 1, pp. 314-315; Sobolewski, supra note 5, p. 401; Kocot, supra note 5, pp. 154-155.

${ }_{96}$ Kocot argues that, apart from the breach of good custom, trust between the parties is necessary for imposing pre-contractual liability. Ibidem, p. 151. Other scholars cite the literal meaning of Article $72 \S 2$, which may be applied when one of the parties "enters into or conducts negotiations in breach of good custom". Rzewuska, Rzewuski, supra note 43, p. 413.

${ }_{97}$ It is worth noting, however, that in most cases the party in breach will also be at fault. Olejniczak, supra note 3, p. 96. However, two possibilities of nonfaulty breach (nonfaulty misrepresentation and nonfaulty denial of information) are mentioned by Machnikowski.
} 
between the conduct of the party at fault and the damages. It should be observed that proving fault before a Polish court of law is a much more strenuous task than proving a breach of contract. This is why the seemingly trivial doctrinal disputes are of major relevance. Thus, it would seem highly advisable for the parties to consider resorting to other means at their disposal, such as concluding a negotiation agreement or a contingent contract, or drafting a letter of intent. Typical instances of illicit negotiating practices contradictory to the good custom principle include: terminating negotiations without a valid cause, raising demands which are impossible to meet, conducting parallel negotiations, not disclosing, or disclosing false information to the other party. The doctrinal majority shares the view that liability based on Article $72 \S 2$ is limited to instances in which the contract has not been concluded as a result of breach of good custom ${ }^{98}$. However, some authors claim that liability may also be imposed in cases when the contract has been completed, but later for some reason found null and void or otherwise defective ${ }^{99}$. Compensation of the damages is limited to the expenses which were unnecessarily incurred in the belief that the contract would be concluded ${ }^{100}$.

Article $72^{1}$ contains a special provision concerning the duty of confidentiality. A party which, during the course of the negotiations, gains possession of information is not entitled to disclose it to other persons or use it in any way if the other party makes a stipulation of confidentiality. Even if a stipulation of this kind is not made, however, the onus of proving that the parties "agreed otherwise" will lie on the party which disclosed the information, according to Article 6 of the Polish Civil Code. The injured party may choose one of the two available remedies: either to demand full compensation of the damages (unrestricted to the party's negative interest and including both losses sustained and benefits lost) ${ }^{101}$ or to demand that the other party hand over the benefits ${ }^{102}$. Article $72^{1}$ may be

Machnikowski, supra note 5, pp. 712-713.

98 Olejniczak, supra note 3, p. 99; Rzewuska, Rzewuski, supra note 43, p. 410.

99 Kubsik, supra note 1, p. 331; Machnikowski, supra note 5, pp. 710-711. Kocot claims that the conclusion of the contract is of no consequence to the imposition of liability. Kocot, supra note 5, p. 157.

100 Known as "negative contractual interest". However, this issue is controversial as some jurists point out that the injured party is entitled to full compensation, similarly to German law. Czachórski, supra note 80, pp. 180-181; Kocot, supra note 5, p. 157. Another controversial issue is whether the "negative contractual interest" includes lost profits. Sobolewski, supra note 5, p. 399. He later grants compensation of lost profits under the condition of proving fault. Ibidem, p. 401.

101 Olejniczak, supra note 3, p. 104.

102 Again, this issue is controversial, as there are voices calling for allowing a combination of the two remedies. Czachórski, supra note 80, p. 180. This runs counter to the literal meaning of 
viewed as a concretisation of the norm set out in the preceding provision, as confidentiality is a sign of loyalty and trust on which pre-contractual negotiations should be based. Czachórski is of the opinion that Article $72^{1}$ is also an example of delictual liability ${ }^{103}$. Other authors, however, tend to differ ${ }^{104}$. At least one other instance of pre-contractual liability in Polish law should be briefly mentioned here. Article 387 Paragraph 2 of the Polish Civil Code creates a duty on the part of the contractor aware of the primary impossibility of the contract's performance to remedy any damages created by the execution of a contract if the other party is unaware of said impossibility ${ }^{105}$. In spite of the haphazard decision of the legislator which sowed discord among the Polish jurists and the growing number of voices calling for a new regulation of pre-contractual liability, the delictual character of culpa in contrahendo in Polish law for the time being appears to be rather cogent.

\section{COMPARISON AND CONCLUSION}

As it has been hypothesised in the introduction, culpa in contrahendo continues to exert its conceptual influence on European legal traditions. However, there exist considerable differences between the national views on the institution, stemming from historical, cultural, and philosophical discrepancies.

Three out of four scrutinised legal systems classify culpa in contrahendo as closer to delictual, or tortious, in the case of English law, rather than contractual liability. Only German law, due to historical reasons, adopts a counter-intuitive and conceptually selective "pre-contractual contract" theory in order to counterbalance the deficiencies of its delictual system,

the provision, but would be in line with model European regulations. Olejniczak, supra note 3, p. 105.

${ }_{103}$ Czachórski, supra note 80, p. 182.

104 S. Dmowski, S. Rudnicki, Komentarz do Kodeksu cywilnego, Księga pierwsza, Część ogólna [The Polish Civil Code wih Commentary, Book One, General Provisions], Warszawa 2011, p. 370. Olejniczak observes that the wording (specifically the mention of non-performance or improper performance) situates Article $72^{1}$ in the immediate vicinity of Article 471, which forms the general principle of contractual liability in Polish law. Moreover, the author believes that Article $72^{1}$, contrary to Article $72 \S 2$, applies when the negotiated contract has been concluded, which is supposedly another argument in favour of his hypothesis. Olejniczak, supra note 3 , pp. 102-103.

$105 \S 2$. A party which, at the time of contract execution, was aware that performance was impossible and did not communicate this to the other party is obliged to remedy any damage the other party suffered by executing the contract while being unaware that performance was impossible. 
which lacks a general liability principle. As a result, the BGB establishes the highest degree of protection for the contracting parties. However, the German model might in certain cases prove to be out of step with the murderous pace of modern-day economic transactions and the everchanging markets, as the lofty standards to which it subjects the contracting parties do not always match actual business practices and may be abused by some courts, overeager in their quest for justice.

In contrast, the English approach, based on nearly absolute freedom of contracting and a casuistic tortious liability system coupled with an obstinate rejection of continental legal solutions does not seem to create the certainty which the English courts hold so dear. The overzealous reliance on traditional concepts coupled with a distrust of abstract concepts may prove to be exceedingly perilous for contractors from other European countries unaware of the legal status quo.

The French and Polish approaches, on the other hand, based on a general delictual liability principle, offer a flexible and harmonious solution, effectively providing the contracting parties with a statutory minimal degree of protection while at the same time allowing the parties to utilise other means of pre-contractual protection. Even these two views on culpa in contrahendo are not free from their shortcomings, however, as French courts tend to exhibit overt paternalism, while Polish courts rarely deal with instances of pre-contractual liability based on Articles $72 \S 2$ and $72^{1}$, which only heightens the jurisprudential confusion surrounding the matter. Moreover, the two legal traditions are unable to adequately justify the contractual components inherent in pre-contractual liability and are overly focused on fault as a prerequisite of liability. The objectivisation tendencies evident in the cited model regulations clearly prove that fault is not required to impose pre-contractual liability. Furthermore, the French and Polish stubborn reliance upon the delictual liability regime may be viewed as a sign of protest against German influences.

Each of the discussed legal systems has accommodated culpa in contrahendo according to its traditions, tendencies and specific needs in order to provide optimal protection for the contracting parties. As it has been pointed out, Jhering's concept in its most primal form combined features of delictual and contractual liability. The national viewson the institution presented in this essay constitute four different modes of tackling culpa in contrahendo's elusive and ambiguous quality and, it seems that all four of them have failed on the theoretical level, as neither of them manages to fully capture the discussed concept. The sole reason for 
their failure is the need for practicality - for providing simple, effective solutions that would fall in line with the existing body of a given country's legal tradition and guarantee protection of the parties' interests and their mutual trust. Considering this, conceptual purity and historical accuracy are of secondary importance. The author, however, wishes to concur with the opinion expressed by Professor Kocot, who calls for the recognition of the sui generis character of pre-contractual liability, and advocates the drafting of new provisions introducing a regime of ex culpae in contrahendo liability. If such a regulation were to be promulgated, Jhering's influential concept could finally achieve full realisation. 

STUDIES 
